\title{
EFFECT OF FERTILIZATIONS AND HERBICIDES ON WEEDS, SOIL MICROORGANISMS AND SOYBEAN PRODUCTION
}

(Received:17.11.2014)

\author{
By \\ A.A.O. Fakkar, A.E.A Ismail and M.H.A. Moharam * \\ Weed Research Central Laboratory, Agriculture Research Center, Giza. \\ *Plant Pathology Department, Faculty Agriculture, Sohag University, Sohag, Egypt
}

\begin{abstract}
The present work was conducted to investigate the effect of fertilizers \{mineral fertilizers (NPK) and organic fertilizer (FYM) and some herbicides (Pendimethalin at the rate of $1.7 \mathrm{l} / \mathrm{fed}$, Prometryn at the rate of $1.0 \mathrm{l} / \mathrm{fed}$, Metolachlor at the rate of $1.0 \mathrm{l} / \mathrm{fed}$, Metribuzin at the rate of $300 \mathrm{~g} / \mathrm{fed}$ and untreated) on weeds, bacterial nodulation and soil microorganisms associated soybean crop during 2012 and 2013 summer seasons.

The results showed that FYM fertilizer significantly increased the dry weight of grassy and broadleaved weeds $\left(\mathrm{g} / \mathrm{m}^{2}\right)$ after 30 days from sowing. Also, it increased the number and dry weight of nodules/plant, the number of soil microorganisms, pod number/plant, pod weight/plant (g), seeds weight / plant (g), seed yield (ton/ fed.) and NPK seed contents \% compared to no fertilizer. This was true in both seasons. All the studied herbicides significantly decreased the dry weight of grassy, broad-leaved weeds and decreased number and dry weight of nodules / plant, number of soil microorganisms and increased pods number /plant, pods weight /plant (g), seeds weight /plant (g), seed yield (ton/fed.) and NPK seed contents \% compared to untreated treatment.

It can be concluded from this study that application of Pendimethalin at the rate of $1.7 \mathrm{l} / \mathrm{fed}$ and Metribuzin at the rate of $300 \mathrm{~g} / \mathrm{fed}$. with FYM fertilizer were the best for weed control and gave the highest soybean yield.
\end{abstract}

Key words: herbicides, microorganisms, nodulation.

\section{INTRODUCTION}

Microorganisms usually occupy a volume of less than $0.1 \%$ of the soil, but are responsible for numerous transformations that cycle elements and energy in nature. The biomass of microorganisms/hectar may reach several tonnes (Torstensson, 1980). The susceptibility of Rhizobium spp. to herbicides has been investigated by a variety of methods, ranging from plate counts of Rhizobium cells to examination of nodulation of legumes (Anderson,1978). Greaves and Malkomes (1980) indicated that the susceptibility of the host plant to herbicides is generally greater than that of the bacterium. Reductions in nodulation and nitrogen- fixation are usually ascribed to plant damage rather than to direct effects of the herbicide on the microorganisms. Kravchenko et al. (2013) revealed that the bacterial populations in the rhizosphere were significantly affected by inoculation. Some undefined bacterial lineages were also found, indicating that soybean rhizosphere may be an important source for the isolation of novel nitrogen-fixing bacteria.

Mclaron and Peterson (1967) pointed out that organic matter plays an essential part in securing soil structure and high fertility. It also acts as a major source of nutrients and energy for the soil microflora.

Hernot and Robertson (1994) stated that soil microbial biomass is a source and sink of soil nutrients, which may be influenced by the $\mathrm{N}$ transformation in soil systems. Soliman et al. (1995) noted that nodulation of soybean was enhanced by inoculation and the highest nodule numbers and fresh mass were obtained with 200 $\mathrm{kgN} / \mathrm{fed}$.. Mohamed and Ezzat (1996) showed that nodule number, nodule weight/plant, straw and seed yields were significantly increased by increasing phosphate rate and inoculation. Zayed (2003) noted that straw, seed yield, 100 -seed weight, nodule fresh weights and nodule numbers were significantly increased 
by inoculation with Rizobia and Phosphate solubilizing bacteria than uninoculated seeds.Gawronska (1997) showed that mineral fertilization also strongly affects a number of microorganisms and qualitative selection of whole communities of soil microorganisms. Sarathchandra et al. (2001) reported that nitrogen and phosphate fertilizers had no significant effects on soil microbial populations and $\mathrm{N}$ application reduced the functional microbial diversity in pasture soils. Barabasz et al. (2002) showed that mineral fertilization of arable land increased the biological productivity of various ecosystems as well as the microbial activity in the soil. Agha et al. (2004) stated that $50 \mathrm{~kg} \mathrm{~N} / \mathrm{ha}+$ inoculation of Rizobia japonicum increased nodule numbers, number of pods per plant, number of seeds per pod, seed weight per plant, seed index, number of nodules per plant and seed yield. Lv et al. (2005) indicated that in addition to providing necessary nutrients for crops and improving soil physico-chemical properties, organic fertilizer is able to enhance soil microbial activity of soil, such as improving the activity of soil enzymes and increasing soil microbial biomass. Cong et al. (2006) showed that microbial biomass and microbial activity were generally higher in organically than conventionally managed soils. Huda (2009) revealed that Rhizobacterien and Phosphorin significantly increased plant height, pod numbers /plant, seed number /pod, seed weight /plant, 100-seed weight, seed yield /fed, nitrate reductive activity, protein and oil \% in soybean. Kelly et al. (2010) found that all inorganic N forms led to a net reduction in microbial respiration, and the magnitude of the observed response (up to $60 \%$ reduction) was consistent across all soils and negatively correlated with $\mathrm{N}$ concentration. Janssens et al. (2010) found that microbial response is a direct effect of the increase in $\mathrm{N}$ availability and if adding different forms of $\mathrm{N}$ would yield a similar response.

Although herbicides are applied to plants and soils to control weeds, they may also affect soil properties, microorganisms. Examinations of herbicide effectes on legume nodulation and growth are important. At present, it seems that the most valuable information comes from measurement of plant growth rather than from more specilized measurements of Rhizobium populations (Greaves and Malkomes, 1980). Zhang et al. (2009) stated that the mineral fertilizer application (N, NP and NPK) did not significantly affect the $\mathrm{N}$ mineralization and soil microbial biomass compared with the $\mathrm{CK}$ under current fertilization conditions.

Miloševic and Govedarica (2002) showed that Azotobacter is the most sensitive to herbicide application. The numbers of this group of nitrogen-fixing bacteria decrease considerably in the period of 7-14 days after herbicide application. Simultaneously, the numbers of Actinomycetes and less so of fungi increase, indicating that these microorganisms use herbicides as sources of biogenous elements. Scholter et al. (2003) noted that many studies have reported the negative as well as the positive effects of the herbicides on soil microbial biomass and soil microorganisms. Khuntia et al. (2013) found that all the herbicides significantly reduced the microbial population up to 15 days after application but recovered later on.

Thus, the present study was designed to investigate the effects of fertilizers and some herbicides on nodules, weeds and soil microorganisms associated soybean crop.

\section{MATERIALS AND METHODS}

This experimental work was carried out during 2013 and 2014 summer seasons in Shandaweel Research Station (Sohag Governorate, Egypt) to investigate the effect of fertilization and some herbicides on weeds, nodules, microorganisms, yield and yield components of soybean (Glycine $\max$ L., cv. Giza 111).

After soil preparation, the experiment area was divided into $10.5 \mathrm{~m}^{2}$ sub plots consisted of five rows $(3.5 \mathrm{~m}$ long and $0.6 \mathrm{~m}$ apart). Seeds were planted after inoculation with the appropriate treatments. Seeds were planted in 10 and 15 June in the two seasons, respectively. Table (1) shows some characteristics of the experimental site. Also Table (2) shows the Trade, common and chemical names of the herbicides. A split plot design with three replications was used in both seasons. The treatments were arranged as follows:

2.1. Fertilizers were allocated in the main plots which were:

2.1.1. NPK (mineral fertilizer) at rate $30 \mathrm{~kg} \mathrm{~N}$ (urea $46.5 \% \mathrm{~N}$ ), $22.5 \mathrm{~kg} \mathrm{P}_{2} \mathrm{O}_{5}$ (superphosphate $15.5 \% \mathrm{P}_{2} \mathrm{O}_{5}$ ) and $24 \mathrm{~kg} \mathrm{~K}$ (potassium sulfate $48 \% \mathrm{~K}_{2} \mathrm{O}$ ) / feddan..

2.1.2. Farm Yard Manure (FYM fertilizer) at the rate $40 \mathrm{~m}^{3} /$ feddan.

2.1.3. Control (Un- fertilizer plots.)

2.2. Weed control treatments in the sub plots were: 
Table (1): Soil characterization of the experimental sites.

\begin{tabular}{|l|l|l|l|l|l|l|l|}
\hline \multirow{2}{*}{ Year } & Texture & CaCO & \multirow{2}{*}{ Soil pH } & \multirow{2}{*}{ O.M\% } & \multicolumn{3}{|c|}{$\begin{array}{c}\text { Available nutrients in } \\
\text { soil (ppm) }\end{array}$} \\
\cline { 6 - 10 } & & & & & N & P & K \\
\hline 2013 & Sandy loam & 7.57 & 7.8 & 0.7 & 14 & 19 & 12 \\
\hline 2014 & Sandy loam & 7.52 & 7.6 & 0.8 & 15 & 18 & 13 \\
\hline
\end{tabular}

Table (2): Trade, common and chemical names of the herbicides used in this study.

\begin{tabular}{|l|l|l|}
\hline Trade name & Common name & \multicolumn{1}{c|}{ Chemical name } \\
\hline Stomp Extra & Pendimethalin & $\begin{array}{l}\text { N-(1-ethylepropyl)-3,4-di-methyl-2,6-dinitrobenzene- } \\
\text { amine }\end{array}$ \\
\hline Gesagard & Prometryn & $\begin{array}{l}\mathrm{N}^{2}, \mathrm{~N}^{4} \text {-di-isopropyl-6-methylthio-1,3,5-triazine-2,4- } \\
\text { diamine }\end{array}$ \\
\hline Sencor & S-Metolachlor & $\begin{array}{l}\text { 2-chloro-6'-ethyl- } N \text {-(2-methoxy-1-methylethyl)aceto- } O \text { - } \\
\text { toluidide }\end{array}$ \\
\hline
\end{tabular}

2.2.1. Stomp extra $45.5 \mathrm{CS} \%$ at rate of $1.51 /$ fed. as pre-emergence

2.2.2. Gesagard $50 \% \mathrm{SC}$ at rate of $1.01 / \mathrm{fed}$. as pre-emergence

2.2.3. Dual Gold $96 \% \mathrm{EC}$ at rate of $1.01 /$ fed. as pre-emergence

2.2.4. Sencor $70 \mathrm{WP} \%$ at rate of $300 \mathrm{~g} / \mathrm{fed}$. as pre-emergence

2.2.5. Unweeded treatment.

Farm Yard Manure (FYM) was added as organic fertilizer at soil preparing.

Phosphorus $\left(15.5 \% \quad \mathrm{P}_{2} \mathrm{O}_{5}\right)$ was added before sowing, both urea $(46.5 \% \mathrm{~N})$ and potassium $\left(48 \% \mathrm{~K}_{2} \mathrm{O}\right)$ was added in one dose before the first irrigation.

Herbicides were sprayed on the soil surface immediately before irrigation as pre-emergence. Using Knapsack sprayer with one nozzle boom and 200 liters water fed. ${ }^{-1}$ as carrier.

The single inoculation was carried out by mixing the bacterial inoculums with soybean seeds; for the combined bacterial inoculations, equal amounts of each inoculums were mixed with soybean seeds. The recommended agricultural practices were carried out throughout the two growing seasons.

\subsection{Recorded data}

\subsection{Weed survey}

Weeds were hand pulled from $1.0 \mathrm{~m}^{2}$ in each subplot after 30 days from sowing. Weeds were identified and classified to grassy and broadleaved weeds to record: dry weight of grassy weed (Echinochola colonum L.) and broad leaved weeds (Xanthium spinosum L., Portulaca oleracea L., Euphorbia peplus L., Corchorus olitorius L. and Amaranthus hybridus L.) g / $\mathrm{m}^{2}$. Weeds were air-dried for seven days and then oven-dried at $70 \mathrm{C}^{\circ}$ for 24 hours until a constant weight.

\subsection{Nodulation}

Sixty days after planting, soybean root samples were collected and washed from the soil particles on $1 \mathrm{~mm}$ sieve holes. Nodules were counted and the number of nodules/plant, fresh weight active nodules/plant (g) were estimated.

\subsubsection{Microorganisms}

\subsubsection{Sampling of soybean rhizosphere microflora}

Root systems of soybean plants, including any adhering soil, were carefully collected at 20 , 40 and 60 days after planting. In each plot, two plants were collected randomly at 20, 40 and 60 days after planting. Samples were transported to the laboratory on ice in plastic bags and processed within $4 \mathrm{~h}$. The roots from each sample were gently removed from the surrounding soil with forceps and any adherent soil was considered part of the rhizosphere. Roots with adherent soil from each sample were cut to pieces then were weighed and placed in 250 or $500 \mathrm{ml}$ flasks containing sterile $1.2 \mathrm{~mm}$ phosphate buffer $(\mathrm{pH}=7)$. This was a 1:10 (root and soil to buffer solution ratio) as determined on an oven dry weight basis. The flasks were put on a rotary shaker for $30 \mathrm{~min}$ and used as stuck suspensions for microbial analysis per gram soil. 


\subsubsection{Media used}

Different semi-solid media were used for the isolation and estimtion of microorganisms from rhizosphere of soybean plants. Peptone-Rose Bengal agar medium (Martin,1950) supplemented with $40 \mathrm{mg}$ streptomycin sulphate $/ 100 \mathrm{ml}$ medium was used for isolating and estimting fungi, whereas nutrient agar (NA) medium was used for bacteria, Ken Knight's agar medium for Actinomycetes (Anarson,1970) and Ashby's mannitol agar medium for Azotobacter estimation (Monkiedje et al. 2002).

\subsubsection{Microbial analysis by serial dilution} and pour plate method

Serial dilution technique and pour plate method described by Dhingra and Sinclair (1995) were used for estimating the total count of isolated bacteria (Azotobacter and Actinomycetes) and fungi associated with soybean roots after application of agrochemicals in treated plots. Serial dilutions of water suspensions were prepared and $1 \mathrm{ml}$ from each stuck suspension of soil rhizosphere was used for isolating microorganisms. Using a fresh sterile micro pipette, $1 \mathrm{ml}$ from each appropriate dilution factor was placed into each of the three Petri dishes. Then approx, $20 \mathrm{ml}$ of molten medium were poured in each plate. After pouring, the plates were immediately gently moved in a whirling motion to mix the contents, left until solidification of the medium and then incubated at $28 \pm 5^{\circ} \mathrm{C}$ in inverted position. After appropriate incubation period, the number of colonies per plate was recorded and the number of colony forming unit (CFU) was counted. Total viable counts are calculated from the following formula.

Total viable count $=$ Average number of colonies $\times$ size of aliquot $\times$ dilution factor.

\subsection{NPK contents $(\%)$}

Plant materials (wet seeds) were digested using a mixture of concentrated sulphuric acid and hydrogen peroxides (Jackson,1958). Phosphorus was determined using chlorostannous reduced molybdophosphoric blue color method in $\mathrm{H}_{2} \mathrm{SO}_{4}$ system and color metrically determined following the method introduced by Jackson (1967). Potassium was photometrically determined using a flame photometer as described by Jackson (1958).

\subsection{Yield and yield components}

At harvest, plant height $(\mathrm{cm})$, number of branches /plant, number of pods/plant, weight of pods /plant (g), weight of seeds /plant (g) and number of seed /plant were determined in a sample of 10 random guarded plants from each sub plot. Seed yield (ton /fed) was calculated on plot basis.

\subsection{Statistical analyses}

The collected data were subjected to statisticall analysis of variance (ANOVA) as split-plot design. The treatment means were compared using the least significant differences (LSD) mentioned by Gomez and Gomez (1984).

\section{RESULTS AND DISCUSSION}

3.1. Effect of fertilization and weed control treatments on

\subsection{Weeds}

The major weeds present in both experimental sites were cocklebur (Xanthium strumarium L.), common purslane (Portulaca oleracea L.), leafy spurge (Euphorbia peplus L.), nalta jute (Corchorus olitorius L.) and pig weed (Amaranthus hybridus L.) as annual broadleaf weeds and branyardgrass (Echinochola colonum L. Link) as annual grassy weed.

Results presented in Table (3) cleared that the

Table( 3): Effect of fertilizations and herbicides on the dry weight of grassy, broad and total weeds in 2012 and 2013 summer seasons.

\begin{tabular}{|c|c|c|c|c|c|c|}
\hline \multirow{2}{*}{ Treatments } & \multicolumn{2}{|c|}{ Grassy weeds } & \multicolumn{2}{|c|}{ Broad-leaved weeds } & \multicolumn{2}{|c|}{ Total weeds } \\
\hline & 2012 & 2013 & 2012 & 2013 & 2012 & 2013 \\
\hline \multicolumn{7}{|c|}{ Fertilizers } \\
\hline NPK fertilizer & 79.2 & 143.5 & 200.9 & 302.5 & 280.1 & 446.0 \\
\hline FYM fertilizer & 161.7 & 192.0 & 301.8 & 338.6 & 463.5 & 530.6 \\
\hline Un-fertilized & 78.7 & 116.7 & 200.7 & 242.5 & 279.4 & 359.1 \\
\hline L.S.D at $5 \%$. & 14.0 & 23.8 & 28.4 & 35.2 & 24.3 & 13.7 \\
\hline \multicolumn{7}{|c|}{ Weed control treatments } \\
\hline Pendimethalin at $1.7 \mathrm{~cm}^{3} / f e d$ & 66.2 & 121.0 & 217.2 & 245.6 & 283.4 & 366.6 \\
\hline Prometryn at $1.0 \mathrm{l} /$ fed & 70.7 & 112.2 & 204.3 & 256.3 & 275.0 & 368.6 \\
\hline Metolachlor at $1.0 \mathrm{l} /$ fed & 87.7 & 136.1 & 210.8 & 271.6 & 298.4 & 407.7 \\
\hline Metribuzin at $300 \mathrm{~cm}^{3} / \mathrm{fed}$ & 105.7 & 140.4 & 179.2 & 277.6 & 284.9 & 418.0 \\
\hline Unweeded treatment & 202.7 & 243.8 & 360.7 & 421.7 & 563.3 & 665.4 \\
\hline L.S.D at $5 \%$ & 22.1 & 22.8 & 34.0 & 27.2 & 36.0 & 34.9 \\
\hline
\end{tabular}


effect of fertilizations and herbicides were significantly reduced in the two categories of the annual weeds (dry weight $\mathrm{g} / \mathrm{m}^{2}$ ).

FYM fertilizer increased the dry weight of grassy, broad-leaved and total weeds by 105.5 , 50.4 and $65.9 \%$ in the first season, respectively, and by $64.5,39.6$ and $47.8 \%$ in second season, respectively, compared with unfertilized treatment. The reduction in the dry weight of the above mentioned weeds in soybean fields might be due to increasing the vegetative growth of soybean plants, which subsequently inhibited the weeds growth. Similar results were obtained by Salas et al. (1997) who indicated that increasing nitrogen increased the dry weight of weeds. Weed population decreased by more than $50 \%$ by applying the bioactive organic fertilizer on soil surface (Hui-lian et al. 2009).

Pendimethalin ( 1.7 1/fed ), Prometryn ( 1.01 /fed ), Metolachlor (1.0 1 /fed.) followed by Metribuzin ( $300 \mathrm{~g} / \mathrm{fed}$.) significantly reduced dry weight of grassy weeds by $67.3,65.1,56.7$ and $47.9 \%$ in the first season, respectively, and $50.4,54.0,44.2$ and $42.4 \%$ in the second season, repetitively. While, Metribuzin, prometryn, Metolachlor and Pendimethalin reduced the dry weight of broadleaf weeds by 50.3, 43.4, 41.6 and 39.8 and \% in the first season, respectively. Meanwhile, Pendimethalin, Prometryn, Metolachlor and Metribuzin decreased the same weeds by $41.8,39.2,35.6$ and $34.2 \%$ in the second season, respectively.

Prometryn, Pendimethalin, Metribuzin and Metolachlor reduced the total weeds percentage by $51.2,49.7,49.4$ and $47.0 \%$ in $1^{s t}$ season, respectively. While, Pendimethalin,Prometryn, Metolachlor and Metribuzin decreased the total weeds by $44.9,44.6,38.7$ and $37.2 \%$ in the $2^{\text {nd }}$ season, respectively. These findings are consistent with those obtained by Sha et al.(2004).

\subsection{Nodulation}

Results presented in Table (4) show that application of FYM and NPK fertilizers significantly increased the number and dry weight of active nodules/ plant compared to unfertilized treatment. Increases in the number and dry weight of active nodules/ plant by FYM were 25.4 , and $13.7 \%$, respectively, and by NPK fertilizers were 30.1 and $14.3 \%$ in the first season, respectively, compared with nonweeded treatment.

The same trend was observed in the second season which were 41.1 and 27.0, respectively, with FYM and 36.4 and $13.6 \%$, respectively, with NPK fertilizers. Similar results were obtained by Soliman et al. (1995), Mohamed and Ezzat (1996), Zayed (2003) and Agha et al. (2004).

Number of active nodules significantly decreased with the application of prometryn, Pendimethalin, Metolachlor and Metribuzin treatments. These reductions were 21.3, 19.3, 18.2 and $129 \%$ in the first season, respectively, compared with unweeded treatments. In the second season, application of Metolachlor, Prometryn, Metribuzin and Pendimethalin decreased the number of active nodules by 24.4 , $20.9,18.7$ and $18.4 \%$, respectively, compared with unweeded. The same trend was found in decreasing the active nodules and dry weight per plant with the application of Prometryn, Pendimethalin, Metolachlor and Metribuzin by $17.9,17.9,14.3$ and $10.7 \%$ in the first season, respectively compared with unnweeded. While, application of Pendimethalin, Metribuzin , Metolachlor and Prometryn decreased the active nodules and dry weight per plant by $14.3,10.7$, 10.7 and $7.1 \%$ in the second season, respectively compared with unweeded.

These results indicated that nodulation of soybean plants is sensitive to the four tested herbicides, as confirmed by González et al., (1996) who reported that the risk of herbicide toxicity to microorganisms may be higher since the metabolism products can inhibit biochemical processes related to symbiosis between plants and microorganisms. Bollich et al. (1985) reported that Metribuzin reduced soybean nodulation and $\mathrm{N} 2$ fixation rate by $50 \%$.

\subsection{Microorganisms}

The results in Tables (5\& 6) and Figs (1-8) showed that application of FYM and NPK fertilizers significantly increased the microbial populations (Bacterial, Actinomycetes, Azotobacter and fungal). In contrast, application of all herbicides significantly decreased the previous traits.

FYM and NPK fertilizers significantly increased bacterial population $\left(10^{6} \mathrm{cfu} / \mathrm{g}\right.$ soil $)$ by 37.8 and $16.8 \%$ at 20 DAT by 32.9 and $12.7 \%$ at $40 \mathrm{DAT}$ and 26.8 and $15.6 \%$ at $60 \mathrm{DAT}$ in the first season, respectively, compared to the control (no fertilizer). In the second season, FYM and NPK fertilizers significantly increased the bacterial population $\left(10^{6} \mathrm{cfu} / \mathrm{g}\right.$ soil $)$ by 17.0 and $11.4 \%$ at 20 DAT by 26.0 and $13.3 \%$, at 40 DAT and 18.8 and $10.6 \%$, at 60 DAT, respectively compared to the control.

The present results in Table(5) showed that 
Table (4): Effect of fertilizers and herbicides on the active nodules/ plant at 60 days after sowing in 2012 and 2013 seasons.

\begin{tabular}{|c|c|c|c|c|}
\hline \multirow[t]{2}{*}{ Treatments } & \multicolumn{2}{|c|}{$\begin{array}{c}\text { Number of active } \\
\text { nodules/ plant }\end{array}$} & \multicolumn{2}{|c|}{$\begin{array}{l}\text { Weight of active } \\
\text { nodules /plant }\end{array}$} \\
\hline & 2012 & 2013 & 2012 & 2013 \\
\hline \multicolumn{5}{|c|}{ Fertilizers } \\
\hline NPK fertilizer & 50.6 & 50.4 & 2.4 & 2.5 \\
\hline FYM fertilizer & 55.8 & 56.0 & 2.9 & 3.0 \\
\hline Un-fertilized & 44.5 & 39.7 & 2.1 & 2.2 \\
\hline L.S.D at 0.05 & 3.57 & 6.23 & $\mathbf{0 . 1 3}$ & 0.19 \\
\hline \multicolumn{5}{|c|}{ Weed control treatments } \\
\hline Pendimethalin at $1.7 \mathrm{~cm}^{3} / f e d$. & 47.4 & 47.6 & 2.3 & 2.4 \\
\hline Prometryn at $1.0 \mathrm{l} /$ fed. & 46.2 & 46.1 & 2.3 & 2.6 \\
\hline Metolachlor at $1.0 \mathrm{l} / \mathrm{fed}$ & 48.0 & 44.1 & 2.4 & 2.5 \\
\hline Metribuzin at $300 \mathrm{~cm}^{3} / f e d$. & 51.1 & 47.3 & 2.5 & 2.5 \\
\hline Unweeded treatment & 58.7 & 58.3 & 2.8 & 2.8 \\
\hline L.S.D at 0.05 & $\mathbf{5 . 3 3}$ & 9.13 & $\mathbf{0 . 2 3}$ & 0.25 \\
\hline
\end{tabular}

Table (5): Effect of fertilizer and herbicides on the total bacterial, and actinomycetes populations.

\begin{tabular}{|c|c|c|c|c|c|c|c|c|c|c|c|c|}
\hline \multirow{3}{*}{ Treatments } & \multicolumn{6}{|c|}{ Bacterial population $\left(10^{6} \mathrm{cfu} / \mathrm{g}\right.$ soil $)$} & \multicolumn{6}{|c|}{ Actinomycetes population (in $10^{4} \mathrm{cfu} / \mathrm{g}$ soil) } \\
\hline & \multicolumn{2}{|c|}{20 days } & \multicolumn{2}{|c|}{40 days } & \multicolumn{2}{|c|}{60 days } & \multicolumn{2}{|c|}{20 days } & \multicolumn{2}{|c|}{40 days } & \multicolumn{2}{|c|}{60 days } \\
\hline & 2012 & 2013 & 2012 & 2013 & 2012 & 2013 & 2012 & 2013 & 2012 & 2013 & 2012 & 2013 \\
\hline \multicolumn{13}{|c|}{ Fertilizers } \\
\hline NPK fertilizer & 22.9 & 30.2 & 26.7 & 34.0 & 42.2 & 37.7 & 8.6 & 5.7 & 6.1 & 6.9 & 5.1 & 4.1 \\
\hline FYM fertilizer & 27.0 & 31.7 & 31.5 & 37.8 & 46.3 & 40.5 & 10.1 & 7.0 & 7.8 & 7.3 & 5.3 & 5.1 \\
\hline Un-fertilized & 19.6 & 27.1 & 23.7 & 30.0 & 36.5 & 34.1 & 6.7 & 4.7 & 5.7 & 4.9 & 4.5 & 3.7 \\
\hline L.S.D at 0.05 & 3.25 & n.s & $\mathbf{3 . 0 2}$ & 2.04 & 4.43 & 1.86 & 0.31 & 1.25 & 0.98 & 1.10 & n.s & 0.26 \\
\hline \multicolumn{13}{|c|}{ Herbicides } \\
\hline $\begin{array}{l}\text { Pendimethalin } \\
\text { at } 1.7 \mathrm{~cm}^{3} / \text { fed. }\end{array}$ & 22.0 & 30.2 & 30.1 & 38.2 & 42.2 & 42.3 & 8.8 & 4.7 & 5.1 & 6.3 & 3.9 & 2.4 \\
\hline $\begin{array}{c}\text { Prometryn at } \\
1.0 \mathrm{l} / \mathrm{fed} .\end{array}$ & 14.6 & 20.3 & 19.3 & 24.2 & 33.9 & 29.6 & 6.6 & 4.2 & 4.6 & 4.4 & 2.7 & 2.0 \\
\hline $\begin{array}{c}\text { Metolachlor at } \\
1.0 \mathrm{l} / \mathrm{fed} .\end{array}$ & 16.7 & 25.6 & 20.1 & 28.1 & 43.2 & 30.4 & 8.3 & 5.6 & 6.0 & 5.0 & 3.6 & 2.9 \\
\hline $\begin{array}{l}\text { Metribuzin at } \\
300 \mathrm{~cm}^{3} / \text { fed. }\end{array}$ & 18.1 & 23.7 & 19.7 & 27.4 & 42.6 & 31.2 & 8.1 & 6.2 & 5.4 & 5.6 & 3.8 & 3.0 \\
\hline $\begin{array}{c}\text { Un-weeded } \\
\text { treatment }\end{array}$ & 44.4 & 48.6 & 47.3 & 51.7 & 46.6 & 53.7 & 10.7 & 7.9 & 11.6 & 10.4 & 10.9 & 11.3 \\
\hline L.S.D at 0.05 & 3.20 & 2.38 & 3.03 & 2.30 & 5.01 & 1.93 & 1.22 & 1.92 & 1.05 & 1.17 & 1.22 & 1.37 \\
\hline
\end{tabular}

the application of Prometryn, Metolachlor, Metribuzin e and Pendimethalin significantly reduced the total bacterial population $\left(10^{6} \mathrm{cfu} / \mathrm{g}\right.$ soil) in the soil at 20 DAT by $67.1,62.4,59.2$ and $50.5 \%$, respectively, in the first season compared to the untreated. Thus, Prometryn, Metribuzin, Metolachlor and Pendimethalin treatments caused a reduction in the total bacterial population which were 58.2, 51.2, 47.3 and $37.9 \%$ in the second season, respectively compared to the untreated. The same trend was observed at 40 and 60 DAT in both seasons.

FYM organic fertilizer increased significantly the actinomycetes population $\left(10^{4} \mathrm{cfu} / \mathrm{g}\right.$ soil $)$ by $50.7,36.8$ and $17.8 \%$, at 20, 40 and 60 DAT in the first season, respectively, and by $48.9,49.0$ and $37.8 \%$, at 20, 40 and 60 DAT, respectively, in the second one. Whilst, NPK mineral fertilizers increased significantly the actinomycetes population $\left(10^{4} \mathrm{cfu} / \mathrm{g}\right.$ soil) by 28.4, 7.0 and $13.3 \%$, at 20, 40 and 60 DAT in the first season, respectively, and by $21.3,40.8$ and $10.8 \%$, at 20, 40 and 60 DAT in the second season, respectively as compared to control.

Application of herbicides decreased the numbers of actinomycetes compared to the control. The reduction in the actinomycete populations was slight at 20 DAT and increased at 40 and 60 DAT. Prometryn, Metribuzin, Metolachlor and Pendimethalin significantly reduced actinomycetes population $\left(10^{4} \mathrm{cfu} / \mathrm{g}\right.$ soil) at 20 DAT by 38.3, 24.3, 22.4 and $17.8 \%$ 
Table (6): Effect of fertilizers and herbicides on azotobacter and fungal populations.

\begin{tabular}{|c|c|c|c|c|c|c|c|c|c|c|c|c|}
\hline \multirow{3}{*}{ Treatments } & \multicolumn{6}{|c|}{ Azotobacter population (in $106 \mathrm{cfu} / \mathrm{g}$ soil) } & \multicolumn{6}{|c|}{ Fungal population (in $103 \mathrm{cfu} / \mathrm{g}$ soil) } \\
\hline & \multicolumn{2}{|c|}{20 days } & \multicolumn{2}{|c|}{40 days } & \multicolumn{2}{|c|}{60 days } & \multicolumn{2}{|c|}{20 days } & \multicolumn{2}{|c|}{40 days } & \multicolumn{2}{|c|}{60 days } \\
\hline & 2012 & 2013 & 2012 & 2013 & 2012 & 2013 & 2012 & 2013 & 2012 & 2013 & 2012 & 2013 \\
\hline \multicolumn{13}{|c|}{ Fertilizers } \\
\hline NPK fertilizer & 20.2 & 23.3 & 25.0 & 25.3 & 34.8 & 28.5 & 3.8 & 8.2 & 7.3 & 11.1 & 11.1 & 14.5 \\
\hline FYM fertilizer & 24.0 & 25.5 & 27.4 & 27.5 & 38.8 & 33.1 & 5.1 & 10.4 & 8.7 & 12.9 & 13.7 & 16.2 \\
\hline Un-fertilized & 17.5 & 20.7 & 20.6 & 22.3 & 32.4 & 26.7 & 2.9 & 7.1 & 7.0 & 9.0 & 9.8 & 12.3 \\
\hline L.S.D at 0.05 & 1.65 & 3.37 & 2.67 & 2.90 & 2.74 & 0.88 & 0.71 & 1.29 & 0.86 & 2.50 & 2.08 & 2.51 \\
\hline \multicolumn{13}{|c|}{ Herbicides } \\
\hline $\begin{array}{l}\text { Pendimethalin } \\
\text { at } 1.7 \mathrm{~cm} 3 / \mathrm{fed} \text {. }\end{array}$ & 24.6 & 25.4 & 33.0 & 24.2 & 36.8 & 32.2 & 3.1 & 4.4 & 7.0 & 10.2 & 10.3 & 14.3 \\
\hline $\begin{array}{c}\text { Prometryn at } \\
1.0 \text { l/fed. }\end{array}$ & 15.0 & 15.7 & 15.4 & 17.7 & 26.2 & 20.0 & 2.8 & 6.3 & 5.6 & 7.9 & 10.1 & 10.9 \\
\hline $\begin{array}{c}\text { Metolachlor at } \\
1.0 \mathrm{l} / \text { fed. }\end{array}$ & 13.9 & 15.9 & 16.8 & 18.1 & 35.2 & 22.8 & 3.6 & 8.1 & 6.7 & 10.4 & 12.6 & 13.9 \\
\hline $\begin{array}{l}\text { Metribuzin at } \\
300 \mathrm{~cm} 3 / \mathrm{fed} \text {. }\end{array}$ & 15.2 & 19.1 & 17.3 & 19.2 & 36.9 & 21.9 & 3.9 & 8.8 & 8.0 & 11.4 & 10.8 & 15.2 \\
\hline $\begin{array}{c}\text { Un-weeded } \\
\text { treatment }\end{array}$ & 34.1 & 38.9 & 39.1 & 46.0 & 41.0 & 50.2 & 6.4 & 11.1 & 11.1 & 15.1 & 13.9 & 17.3 \\
\hline L.S.D at 0.05 & 2.01 & 1.69 & 2.24 & 2.24 & 2.62 & 2.48 & 0.73 & 1.72 & 1.16 & 1.72 & 2.15 & 2.30 \\
\hline
\end{tabular}

in the first season, respectively, compared to the untreated. Meanwhile,Prometryn,Pendimethalin, Metolachlor and Metribuzin treatments reduced actinomycetes population by $46.8,40.5,29.1$ and $21.5 \%$ in the second season, respectively, compared to the control. The same trend was observed at 40 and 60 DAT in both seasons.

The present results showed that Prometryn herbicide, had an inhibitory effect on the numbers of actinomycete populations compared to other herbicides and the control. FYM and NPK fertilizers significantly increased the azotobacter population $\left(10^{6} \mathrm{cfu} / \mathrm{g}\right.$ soil) by 37.1 and $15.4 \%$ at 20 DAT, respectively, 33.0 and $21.4, \%$ at 40 DAT, respectively, and 19.8 and $7.4 \%$ at 60 DAT, respectively, compared to control in the first season. In the second season, FYM and NPK fertilizers significantly increased azotobacter population $\left(10^{6} \mathrm{cfu} / \mathrm{g}\right.$ soil) by 23.2 and $12.6 \%$ at 20 DAT, respectively 23.3 and $13.5 \%$, at 40 DAT and 24.0 and $6.7 \%$, at 60 DAT, respectively, compared to control.

The results in Table (6) idicate that the application of Metolachlor, Prometryn, Metribuzin and Pendimethalin caused greater reduction in azotobacter population $\left(10^{6} \mathrm{cfu} / \mathrm{g}\right.$ soil) present in the soil at 20 DAT, by 59.2, 56.0, 55.4 and $27.9 \%$ in the first season, respectively, compared with the untreated. Thus, Prometryn, Metolachlor, Metribuzin and Pendimethalin treatments reduced azotobacter population by 59.6, 59.1, 50.9 and $34.7 \%$ in the second season , respectively compared to the untreated. The same trend was observed at 40 and 60 DAT in both seasons.

Results in Table (6) showed that the application of FYM and NPK fertilizers significantly increased the population of soil fungi at 20 DAT by 75.9 and $31.0 \%$, by 24.3 and $4.3 \%$, at 40 DAT and by 39.8 and $13.3 \%$, at 60 DAT in the first season, respectively. Meanwhile, the prevoius fertilizers increased the population of soil fungi by 46.5 and $15.5 \%$ at 20 DAT, respectively, 43.3 and $23.3 \%$, at 40 DAT respectively, and 31.7 and $17.9 \%$, at 60 DAT, respectively in the second season compared with control.

The results in Table (6) showed that all the used herbicides decreased the population of soil fungi compared with the control. Application of Prometryn, Pendimethalin, Metolachlor and Metribuzin caused a greater reduction in soil fungi population $\left(10^{3} \mathrm{cfu} / \mathrm{g}\right.$ soil $)$ at 20 DAT by $56.3,51.6,43.8$ and $39.1 \%$ in the first season, respectively compared to the untreated. Thus, Pendimethalin , Prometryn, Metolachlor and Metribuzin reduced soil fungi population by $60.4,43.2,27.0$ and $20.7 \%$, respectively, in the second season compared to the untreated. The same trend was observed at 40 and 60 DAT in both seasons. The present results are in agreement with those reported by Gawronska (1997), Barabasz et al. (2002), Miloševic and Govedarica (2002), Scholter et al. (2003), Lv et al. (2005), Cong et al. (2006), Janssens et al. (2010) and Khuntia et al (2013) . 


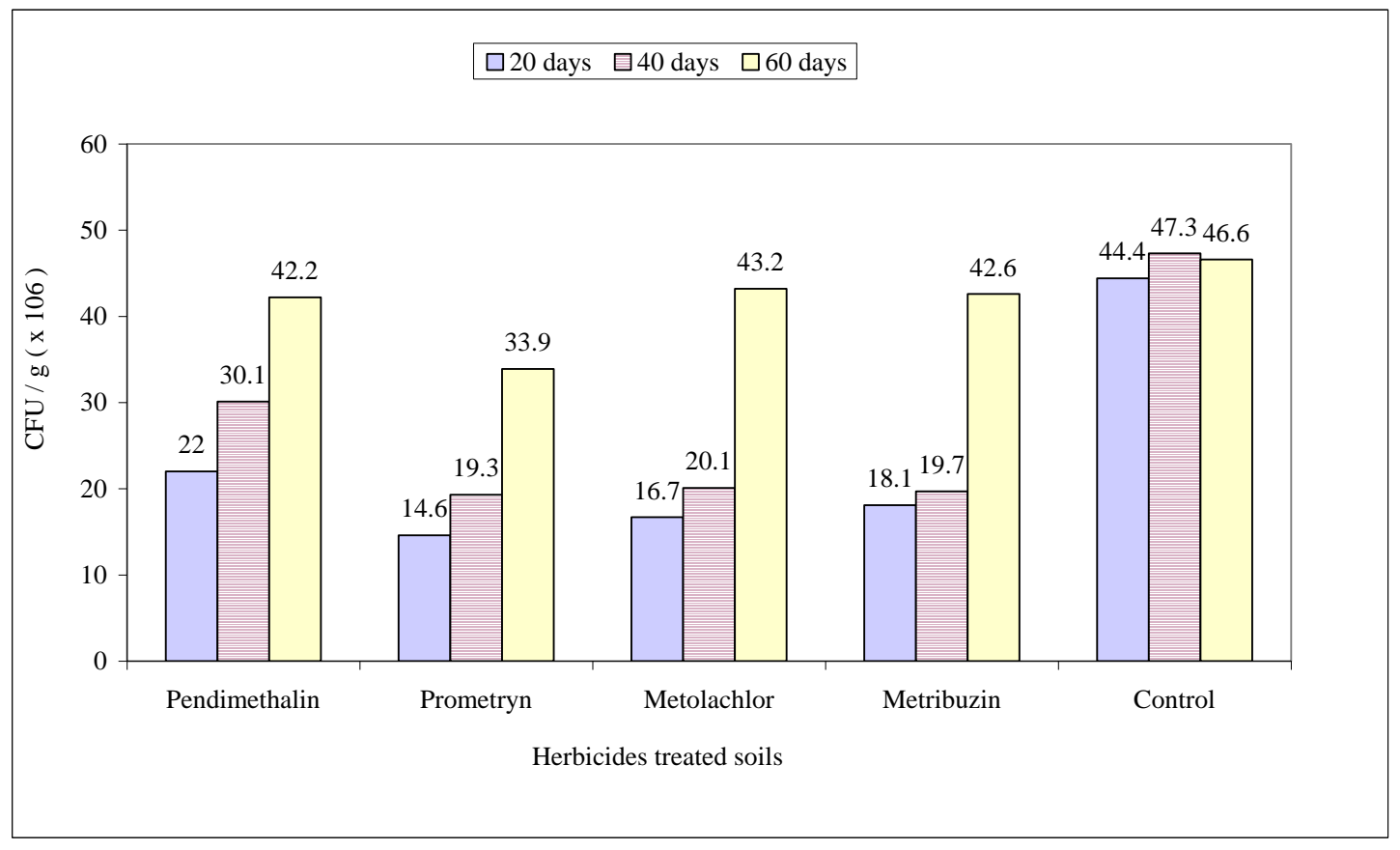

Fig. (1): Effect of herbicides on soil bacterial populations in 2012 season.

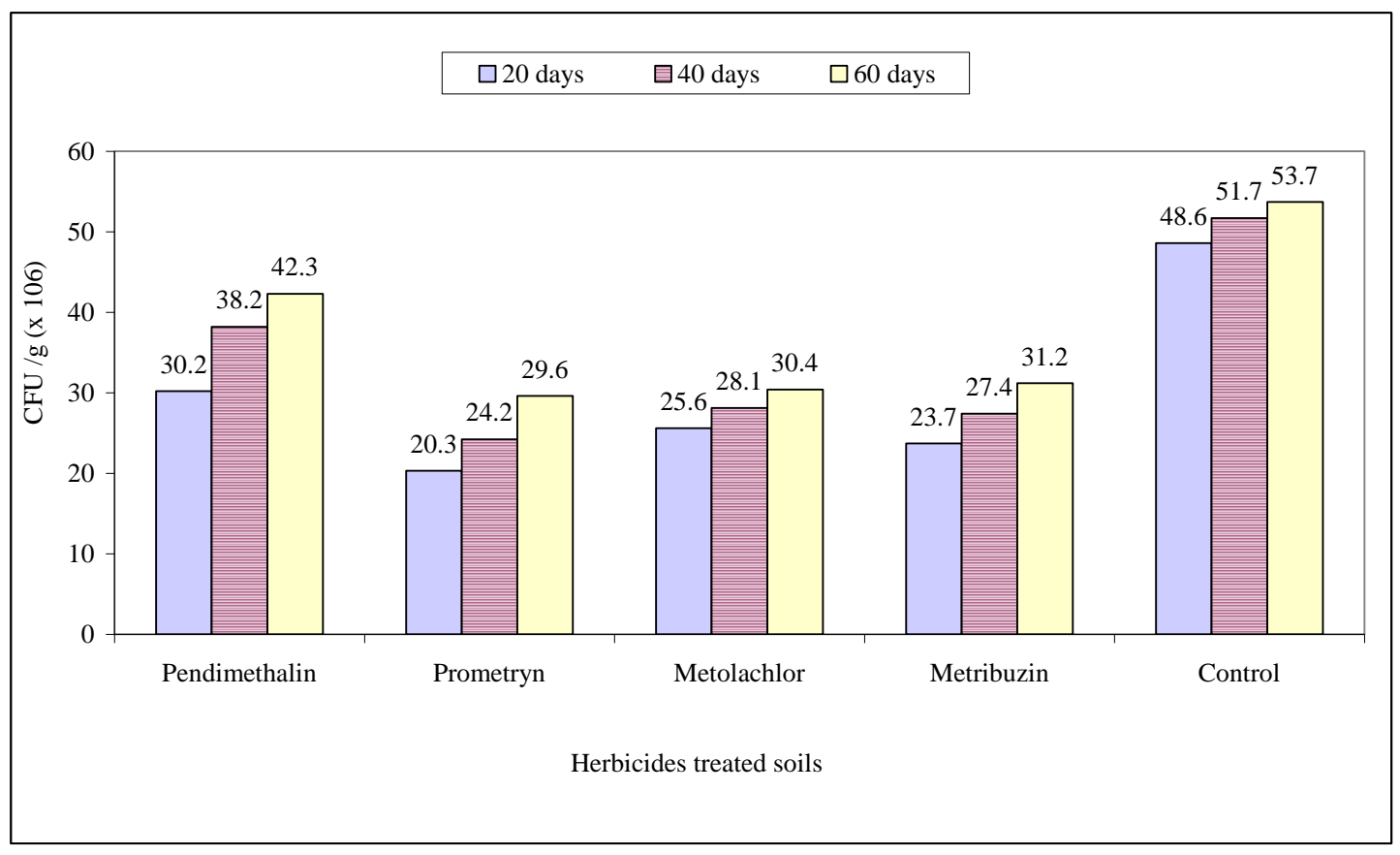

Fig. (2): Effect of herbicides on soil bacterial populations in 2013 season. 


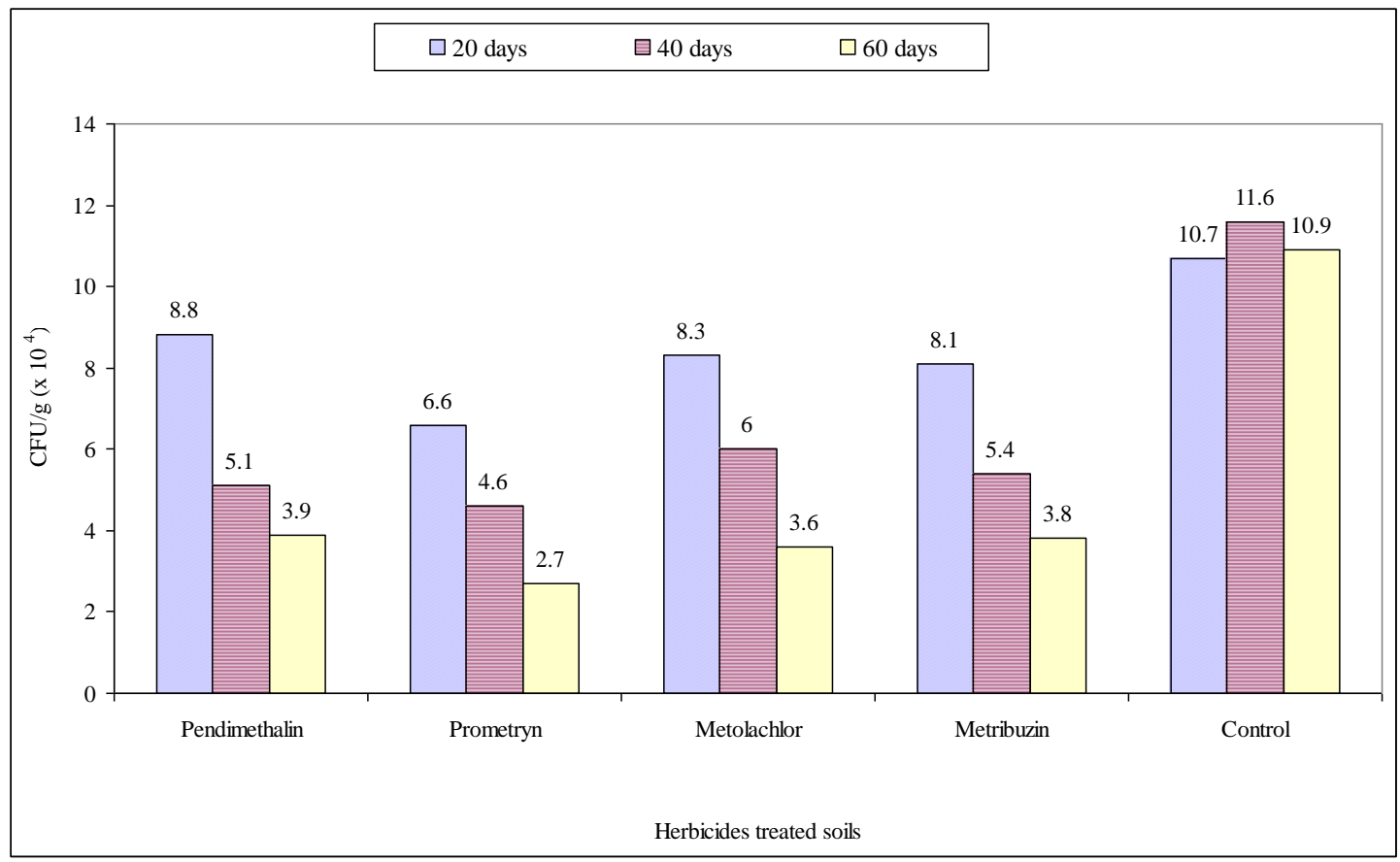

Fig. (3): Effect of herbicides on soil actinomyces populations in 2012 season.

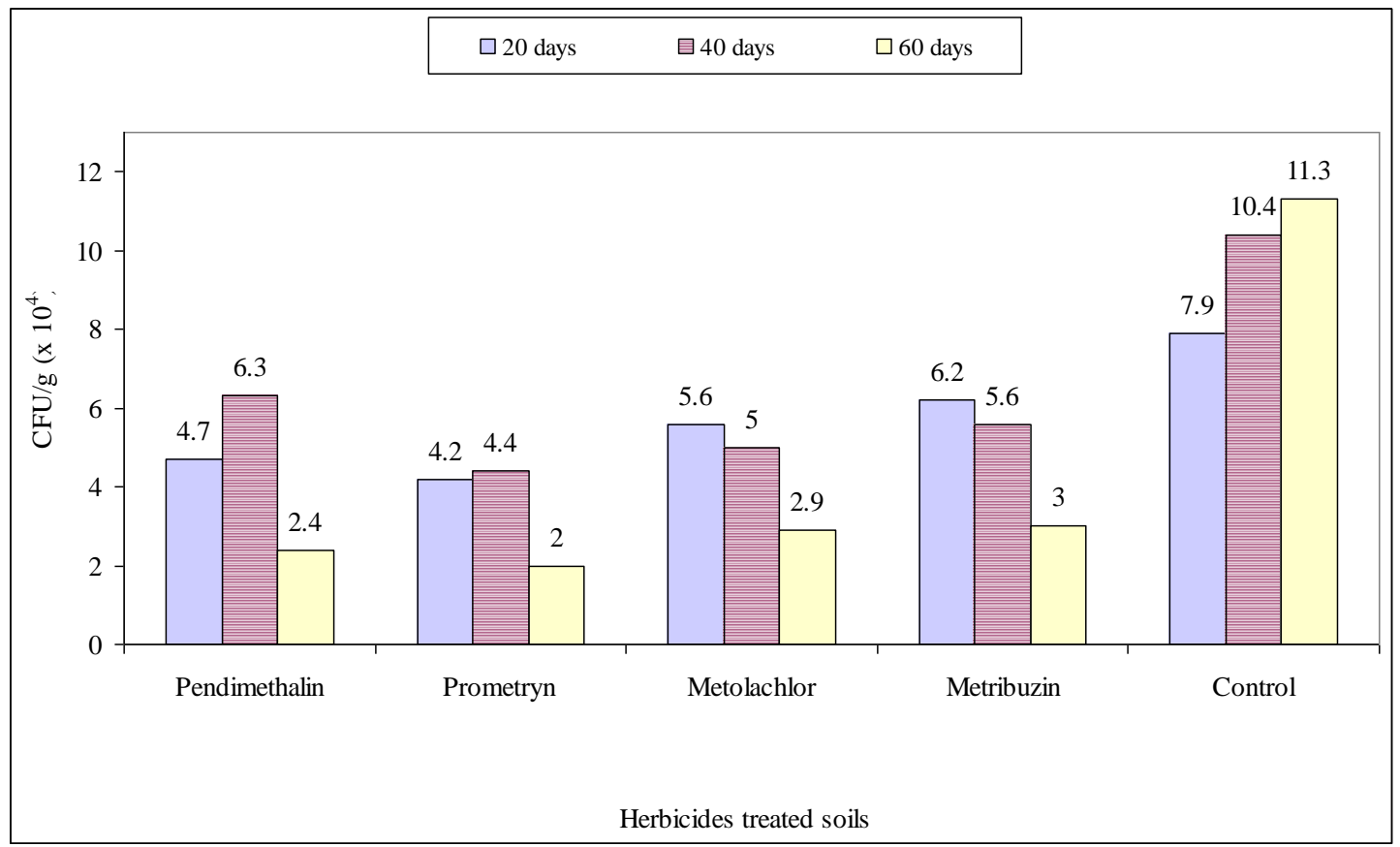

Fig. (4): Effect of herbicides on soil actinomyces populations in 2013 season. 


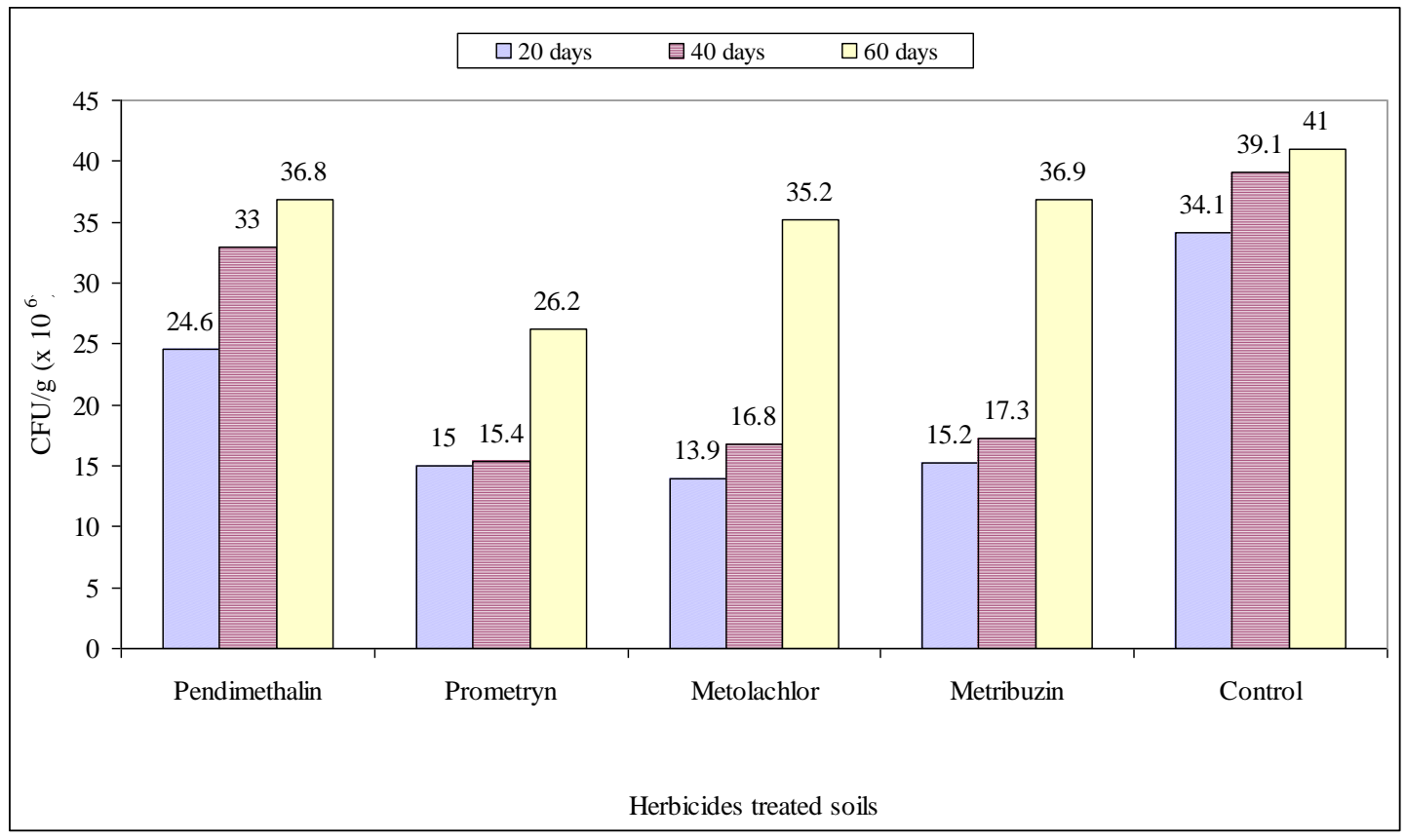

Fig. (5): Effect of herbicides on soil azotobacter populations in 2012 season.

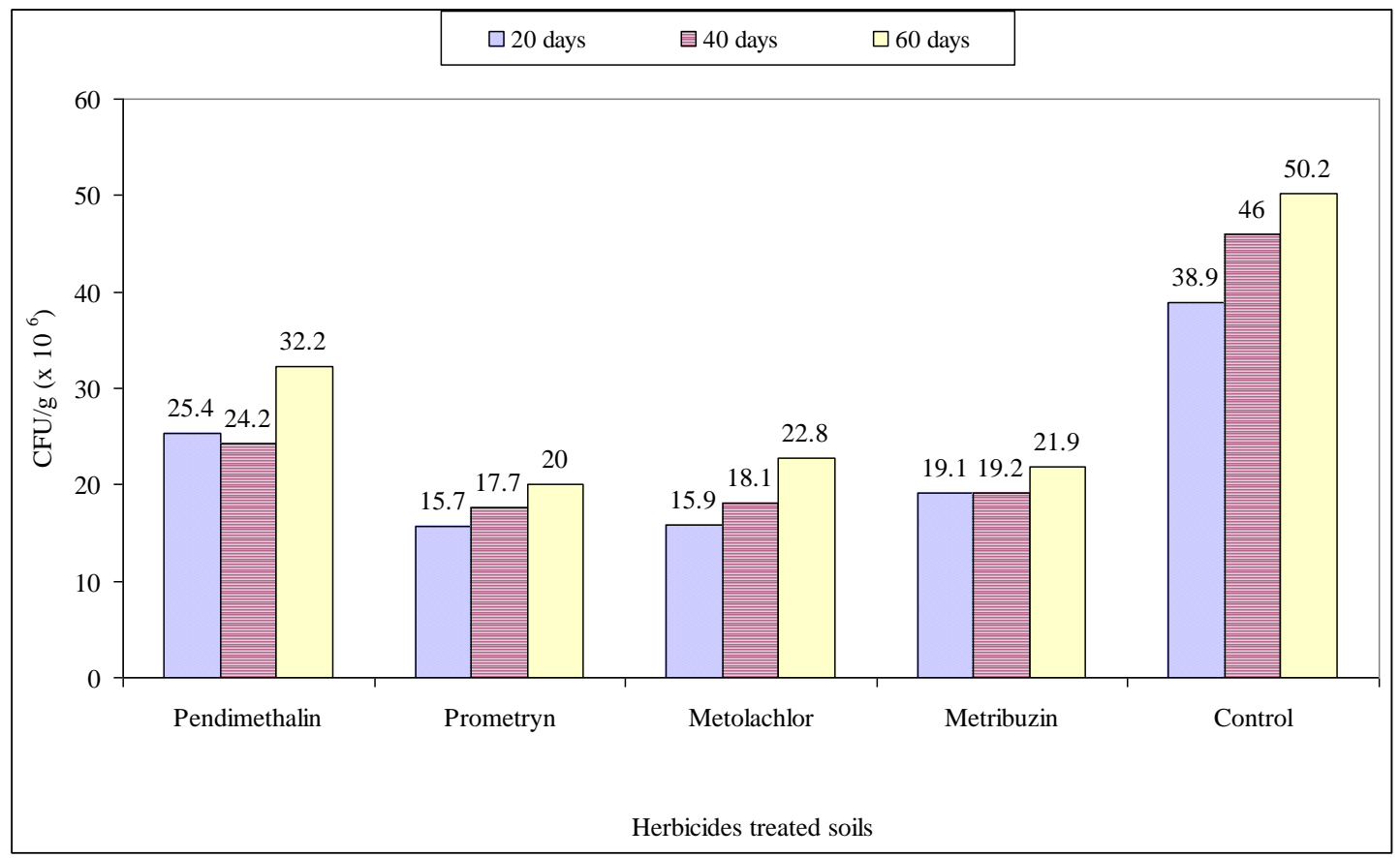

Fig. (6): Effect of herbicides on soil azotobacter populations in 2013 season. 


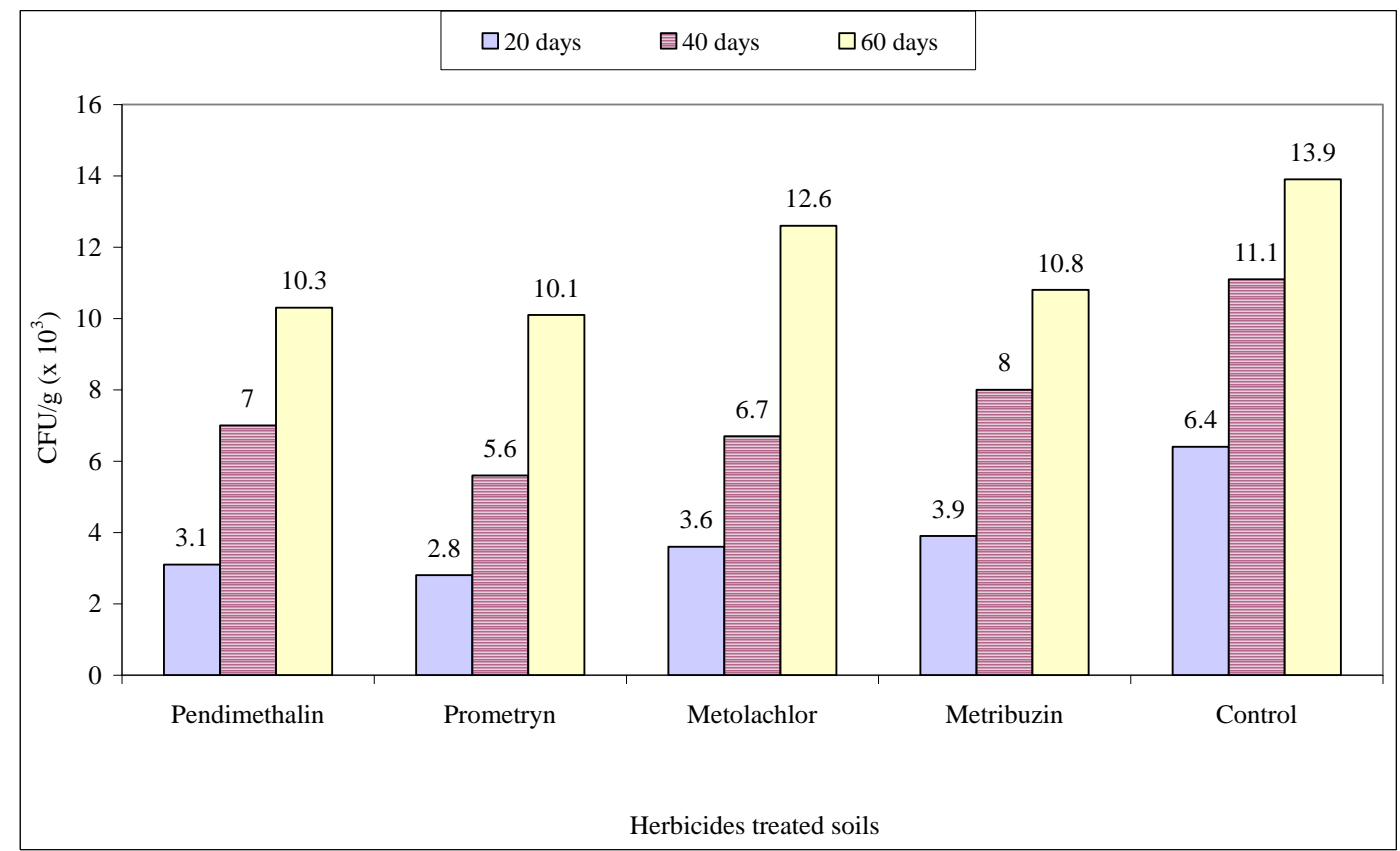

Fig. (7): Effect of herbicides on soil fungal populations in 2012 season.

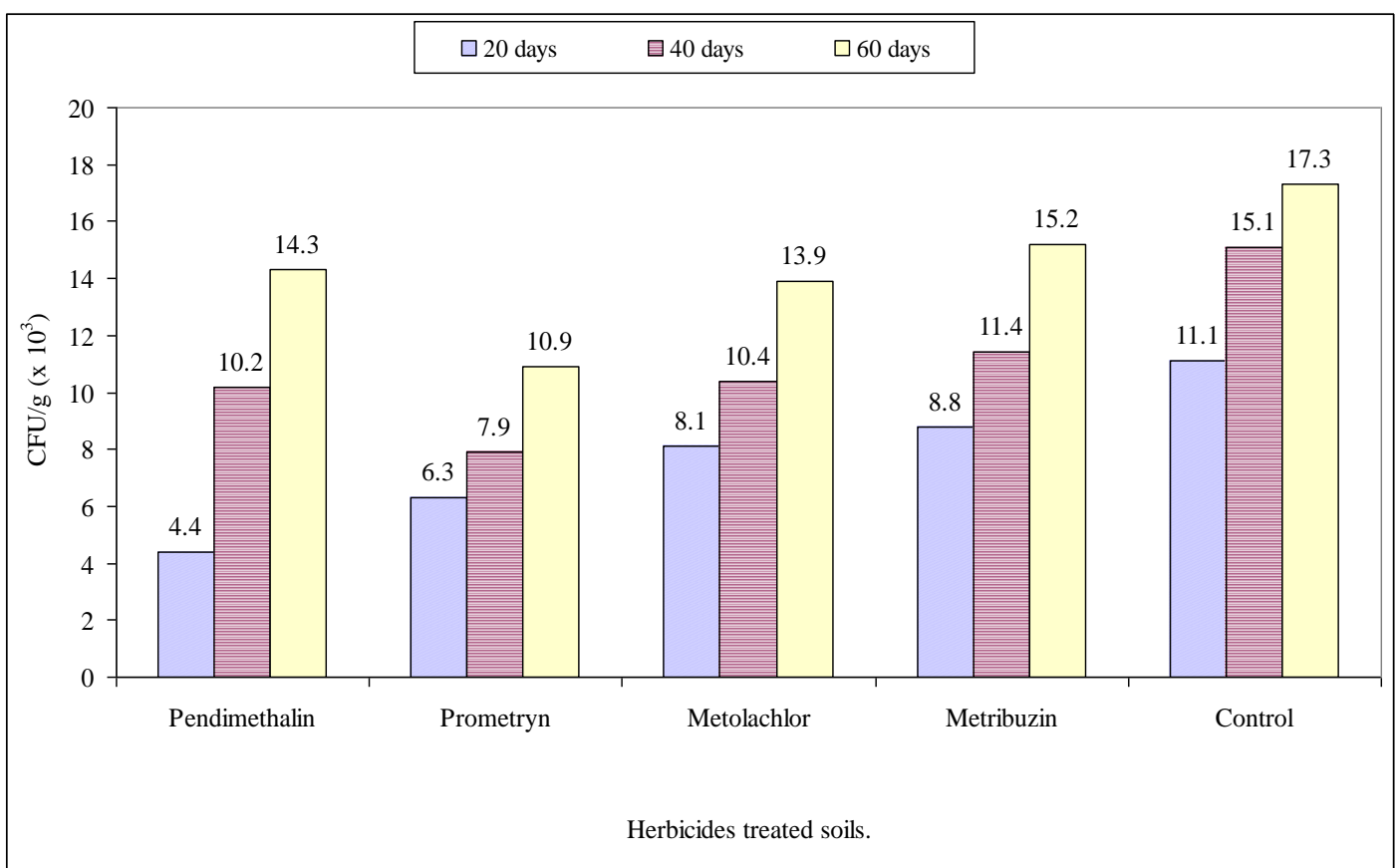

Fig. (8): Effect of herbicides on soil fungal populations in 2013 season.

\subsection{Soybean yield, yield components}

Results presented in Tables (7) and (8) showed that the application of fertilizers and herbicides significantly affect the soybean yield and its attributes. FYM fertilizers effect on soybean yield and its attributes was significant in both seasons except with plant height in the first season. Application of FYM gave the superior values for all the studied characteristics. In regard to seed yield (ton /fed.) in both seasons, the higher values (37.9 and $40.9 \%$ ) were obtained by FYM fertilizers compared to nofertilizer in both seasons, respectively. This in turn, accelerated the vegetative growth, enhances the photosynthetic activity which eventually form the carbohydrate pools, yield and yield components were subsequently increased. The results are also in good agreement with those obtained by Mohamed and Ezzat (1996), Agha et al. (2004), Hoda (2009) and Janssens et al. (2010). 
Table (7): Effect of fertilizers and herbicides on yield components of soybean

\begin{tabular}{|c|c|c|c|c|c|c|c|c|c|c|}
\hline \multirow[t]{2}{*}{ Treatments } & \multicolumn{2}{|c|}{$\begin{array}{l}\text { Plant height } \\
\quad(\mathrm{cm})\end{array}$} & \multicolumn{2}{|c|}{$\begin{array}{c}\text { Pods } \\
\text { number } \\
\text { /plant }\end{array}$} & \multicolumn{2}{|c|}{$\begin{array}{l}\text { Pods weight } \\
\text { /plant (g) }\end{array}$} & \multicolumn{2}{|c|}{$\begin{array}{l}\text { Seeds weight } \\
\text { /plant (g) }\end{array}$} & \multicolumn{2}{|c|}{$\begin{array}{l}100 \text { Seed } \\
\text { Weight }(\mathrm{g})\end{array}$} \\
\hline & 2012 & 2013 & 2012 & 2013 & 2012 & 2013 & 2012 & 2013 & 2012 & 2013 \\
\hline \multicolumn{11}{|c|}{ Fertilizers } \\
\hline NPK fertilizer & 97.6 & 90.0 & 63.3 & 62.2 & 92.4 & 84.1 & 79.1 & 71.5 & 21.3 & 21.7 \\
\hline FYM fertilizer & 100.8 & 100.8 & 70.5 & 72.1 & 101.7 & 92.2 & 87.9 & 80.2 & 22.5 & 23.1 \\
\hline Un-fertilized & 97.4 & 89.7 & 44.7 & 44.0 & 79.0 & 69.1 & 66.3 & 57.1 & 19.5 & 19.6 \\
\hline L.S.D at 0.05 & n.s & 9.21 & 2.7 & 8.39 & 9.7 & 3.53 & 14.5 & 4.63 & 0.59 & 0.44 \\
\hline \multicolumn{11}{|c|}{ Herbicides } \\
\hline $\begin{array}{c}\text { Pendimethalin at } 1.7 \\
\mathrm{~cm}^{3} / \mathrm{fed} \text {. }\end{array}$ & 100.6 & 93.4 & 63.1 & 60.2 & 93.4 & 76.8 & 80.7 & 65.4 & 21.5 & 21.7 \\
\hline Prometryn at $1.0 \mathrm{l} / \mathrm{fed}$. & 94.6 & 94.9 & 59.1 & 64.0 & 96.6 & 86.0 & 83.1 & 75.4 & 21.7 & 22.0 \\
\hline $\begin{array}{c}\begin{array}{c}\text { Metolachlor at 1.0 } \\
\text { l/fed. }\end{array} \\
\end{array}$ & 100.8 & 93.6 & 59.3 & 65.0 & 96.9 & 78.9 & 84.7 & 67.7 & 21.4 & 21.7 \\
\hline $\begin{array}{c}\text { Metribuzin at } 300 \\
\mathrm{~cm}^{3} / \mathrm{fed} .\end{array}$ & 102.4 & 93.1 & 61.8 & 61.7 & 97.0 & 80.2 & 84.1 & 67.7 & 21.5 & 21.5 \\
\hline Unweeded treatment & 94.7 & 92.5 & 54.1 & 46.3 & 71.2 & 87.1 & 56.2 & 71.9 & 19.5 & 20.2 \\
\hline L.S.D at 0.05 & n.s & n.s & n.s & 7.36 & 8.6 & n.s & 9.0 & n.s & 0.76 & 0.68 \\
\hline
\end{tabular}

Table (8) : Effect of fertilizers and herbicides on soybean yield and NPK seed contents.

\begin{tabular}{|c|c|c|c|c|c|c|c|c|}
\hline \multirow{3}{*}{ Treatments } & \multirow{2}{*}{\multicolumn{2}{|c|}{$\begin{array}{c}\text { Seed yield } \\
\text { ton/fed }\end{array}$}} & \multicolumn{6}{|c|}{ Seed contents \% } \\
\hline & & & \multicolumn{2}{|c|}{$\mathbf{N}$} & \multicolumn{2}{|c|}{$\mathbf{P}$} & \multicolumn{2}{|c|}{$\mathbf{K}$} \\
\hline & 2012 & 2013 & 2012 & 2013 & 2012 & 2013 & 2012 & 2013 \\
\hline & \multicolumn{8}{|c|}{ Fertilizers } \\
\hline NPK fertilizer & 2.15 & 2.25 & 5.48 & 5.45 & 0.343 & 0.336 & 3.04 & 3.18 \\
\hline FYM fertilizer & 2.69 & 2.79 & 5.64 & 5.72 & 0.357 & 0.369 & 3.39 & 3.55 \\
\hline Un-fertilized & 1.95 & 1.98 & 4.77 & 4.45 & 0.284 & 0.262 & 2.68 & 2.72 \\
\hline \multirow[t]{2}{*}{ L.S.D at 0.05} & 0.08 & 0.24 & $\mathbf{0 . 3 3}$ & 0.24 & $\mathbf{0 . 0 1}$ & 0.01 & 0.27 & 0.16 \\
\hline & \multicolumn{8}{|c|}{ Herbicides } \\
\hline Pendimethalin at $1.7 \mathrm{~cm}^{3} / \mathrm{fed}$. & 2.30 & 2.56 & 5.47 & 5.43 & 0.346 & 0.349 & 3.24 & 3.30 \\
\hline Prometryn at $1.0 \mathrm{l} / \mathrm{fed}$. & 2.27 & 2.25 & 5.64 & 5.56 & 0.344 & 0.346 & 3.36 & 3.34 \\
\hline Metolachlor at 1.0 l/fed. & 2.29 & 2.40 & 5.52 & 5.33 & 0.335 & 0.331 & 3.06 & 3.11 \\
\hline Metribuzin at $300 \mathrm{~cm}^{3} / \mathrm{fed}$. & 2.41 & 2.37 & 5.52 & 5.20 & 0.334 & 0.314 & 3.00 & 3.20 \\
\hline Un-weeded treatment & 2.06 & 2.12 & 4.77 & 4.52 & 0.281 & 0.272 & 2.53 & 2.82 \\
\hline L.S.D at 0.05 & 0.17 & 0.21 & 0.17 & 0.20 & 0.02 & 0.02 & 0.16 & 0.17 \\
\hline
\end{tabular}

It can be seen in Tables $(7 \& 8)$ that all herbicides significantly increased growth characteristics and yield of soybean except plant height, pods number in the first season and plant height, pods weight per plant ${ }^{-1}$ and seed weight per plant ${ }^{-1}$ in the second one. All herbicides gave the superior values for all studied characteristics compared to un-weeded treatment in both seasons.

In addition, application of Prometryn was the best treatment to increase 100 -seed weight compared to un-weeded treatment in both seasons. On the other hand, Metribuzin, Pendimethalin and Metolachlor treatments had the highest seed yield (ton/ fed. ${ }^{-1}$ ) in the first season and Pendimethalin, Metolachlor and Metribuzin in the second season compared with the un-weeded treatment. These treatments increased seed yield over un-weeded treatment by $17.0,11.7$ and $11.2 \%$ in the first season, respectively, and by $20.8,13.2$ and $11.8 \%$ in the second one, respectively. Superiority of these treatments is correlated with their efficiency for controlling soybean associated weeds, limiting weeds infestation and minimizing weed competition.

FYM and NPK fertilizers caused significant increase in the NPK contents in the seeds compared with unfertilized treatments in both seasons (Table 8). FYM fertilizer gave the highest values of NPK contents in the seeds followed by NPK fertilizer compared with the unfertilized treatments in both seasons. 
Results presented in Table (8) showed that weed control treatments increased the mean value of NPK contents (\%) in seeds in both seasons. Application of Prometryn gave the highest values of $\mathrm{N}$ content (\%) in the seeds by 18.2 and $23.0 \%$ in both seasons, respectively and Pendimethalin for $\mathrm{P}$ content $(\%)$ in the seeds (23.1 and $28.3 \%)$ in both seasons, respectively. Application of Prometryn gave the highest values of $\mathrm{K}$ content $(\%)$ in seeds $(32.8$ and $18.4 \%)$ in both seasons, respectively, compared with un-weeded treatment. Weed control chemically may be increased amount of nutrients absorbed by the roots which resulted in increased NPK contents in soybean seeds. Weed control mechanically or chemically may be increased amount of nutrients absorbed by the roots which resulted in increased NPK contents in soybean seeds.

3.2. Interaction between fertilization and weed control treatments
All interactions effects between fertilizers and weed control treatments on all characteristic study were significant at (0.05) level on the population of soil fungi at 20 and 40 DAT in the first season, dry weight of broad-leaf, total weeds and $\mathrm{N}$ content $\%$ in the seeds in the second season, meaning that the two factors act independently and their data were excluded (Table 9). All herbicides gave the highest reduction on dry weight of broad-leaf and total weeds under non- fertilizing (control).

Results in Table (9) showed that all interactions between non-fertilizing and prometryn, Pendimethalin, Metolachlor and Metribuzin gave the highest reduction in dry weight of broad-leaf by $62.2,58.8,55.8$ and $52.7 \%$ and total weeds by $67.7,63.0,59.7$ and $56.4 \%$, respectively compared to FYM fertilizers with un- treated.

Interactions between FYM fertilizers with the un-treated gave the highest values of soil fungi

Table( 9): Effect of the interaction between fertilization and weed control treatments on the number and weight of nodules/plant in 2012 season and broad leaf, total weeds $\left(\mathrm{g} / \mathrm{m}^{2}\right)$ and $\mathrm{N}$ seed content $\%$ in 2013 season.

\begin{tabular}{|c|c|c|c|c|c|c|}
\hline \multirow{3}{*}{ Fertilization } & \multirow{3}{*}{ Weed control } & \multirow{2}{*}{\multicolumn{2}{|c|}{$\begin{array}{c}2012 \text { season } \\
\text { Fungal population } \\
\text { (in } 10^{3} \mathrm{cfu} / \mathrm{g} \text { soil) }\end{array}$}} & \multicolumn{3}{|c|}{2013 season } \\
\hline & & & & \multirow{2}{*}{$\begin{array}{l}\text { Broad-leaf } \\
\text { weeds } \\
\left(\mathrm{g} / \mathbf{m}^{2}\right)\end{array}$} & \multirow{2}{*}{$\begin{array}{c}\text { Total } \\
\text { Weeds } \\
\left(\mathrm{g} / \mathrm{m}^{2}\right)\end{array}$} & \multirow{2}{*}{$\begin{array}{c}\text { N Seed } \\
\text { contents } \\
\%\end{array}$} \\
\hline & & 20 days & 40 days & & & \\
\hline \multirow{5}{*}{ NPK } & $\begin{array}{l}\text { Pendimethalin } \\
\text { at } 1.7 \mathrm{~cm}^{3} / \text { fed. }\end{array}$ & 3.00 & 5.0 & 264.0 & 378.7 & 5.630 \\
\hline & $\begin{array}{l}\text { Prometryn at } \\
1.0 \text { l/fed. }\end{array}$ & 2.67 & 6.0 & 264.3 & 383.0 & 5.730 \\
\hline & $\begin{array}{l}\text { Metolachlor at } \\
1.0 \text { l/fed. }\end{array}$ & 3.33 & 6.33 & 280.7 & 409.7 & 5.503 \\
\hline & $\begin{array}{l}\text { Metribuzin at } \\
300 \mathrm{~cm}^{3} / \text { fed. }\end{array}$ & 4.00 & 7.67 & 291.0 & 418.0 & 5.697 \\
\hline & Unweeded & 6.00 & 11.33 & 412.7 & 640.7 & 4.693 \\
\hline \multirow{5}{*}{ FYM } & $\begin{array}{l}\text { Pendimethalin } \\
\text { at } 1.7 \mathrm{~cm}^{3} / \mathrm{fed} .\end{array}$ & 4.00 & 8.0 & 262.3 & 414.7 & 5.767 \\
\hline & $\begin{array}{l}\text { Prometryn at } \\
1.0 \text { l/fed. }\end{array}$ & 3.33 & 5.67 & 311.3 & 455.7 & 5.987 \\
\hline & $\begin{array}{l}\text { Metolachlor at } \\
1.0 \text { l/fed. }\end{array}$ & 4.00 & 8.0 & 308.7 & 480.0 & 5.960 \\
\hline & $\begin{array}{l}\text { Metribuzin at } \\
300 \mathrm{~cm}^{3} / \text { fed. }\end{array}$ & 5.00 & 9.0 & 300.3 & 475.7 & 5.663 \\
\hline & Unweeded & 9.33 & 13.0 & 510.3 & 827.0 & 5.233 \\
\hline \multirow{5}{*}{ Unfertilized } & $\begin{array}{l}\text { Pendimethalin } \\
\text { at } 1.7 \mathrm{~cm}^{3} / \mathrm{fed} .\end{array}$ & 2.33 & 8.0 & 210.3 & 306.3 & 4.893 \\
\hline & $\begin{array}{l}\text { Prometryn at } \\
1.0 \text { l/fed. }\end{array}$ & 2.33 & 5.0 & 193.0 & 267.0 & 4.953 \\
\hline & $\begin{array}{l}\text { Metolachlor at } \\
1.0 \text { l/fed. }\end{array}$ & 3.33 & 5.67 & 225.3 & 333.3 & 4.540 \\
\hline & $\begin{array}{l}\text { Metribuzin at } \\
300 \mathrm{~cm}^{3} / \text { fed. }\end{array}$ & 2.67 & 7.33 & 241.3 & 360.3 & 4.230 \\
\hline & Unweeded & 4.00 & 9.0 & 342.0 & 528.7 & 3.620 \\
\hline \multicolumn{2}{|c|}{ L.S.D. 0.05} & 0.45 & 1.22 & 47.2 & 60.6 & 0.33 \\
\hline
\end{tabular}


population at 20 and 40 DAT compared to the un- fertilized with Prometryn.

Interactions between FYM fertilizers and Prometryn herbicide increased $\mathrm{N}$ content $\%$ in seeds compared to un- fertilized with unweeded.

\section{REFERENCES}

Agha S.K., Oad F.C. and Buriro U. A. (2004). Yield and yield components of inoculated and un-inoculated soybean under varying nitrogen levels. Asian J. Plant Sci., 3 (3): 370-371.

Anarson S. (1970). Experimental Microbial Ecology. Academic Press, NewYork. Bacteriology. McGraw Hill, New York,USA, $201 \mathrm{pp}$.

Anderson J.R.(1978).In: Pesticide Microbiology, Academic Press, London, UK,pp. 313-533.

Barabasz W., Albińska D., Jaśkowska M. and Lipiec J. (2002). Biological effects of mineral nitrogen fertilization on soil microorganisms. Polish J. of Environ. Studies, 11 (3): 193-198.

Bollich P. K., Dunnigan E. P. and Jadi A. W. M. (1985). Effects of seven herbicides on N2 $(\mathrm{C} 2 \mathrm{H} 2)$ fixation by soybeans. Weed Sci., 33: 427.

Cong Tu., Jean B. Ristaino and Shuijin Hu. (2006). Soil microbial biomass and activity in organic tomato farming systems:Effects of organic inputs and straw mulching. Soil Biol. \& Biochem., 38: 247-255.

Dhingra, O.D. and Sinclair J.B. (1995). Basic plant pathology method. Second Edition, Lewis Publishers, CRC Press, USA, 434 pp.

Gawronska A. (1997). Crop rotation of plants and soil infestation. Acta Acad. Agri. Tech. Olst. Agric., 64: 67. (in Polish).

Gomez K.A. and Gomez A.A. (1984). Statistical Procedures for Agricultural Research. John Wiley and Sons. Inc, New York, U.S.A.

González A., González -Murua C. and Royuela M. (1996). Influence of imazethapyr on Rhizobium growth and its symbiosis with pea (Pisum sativum). Weed Sci., 44: 31-37.

Greaves M. P. and Malkomes H. P. (1980). Effect on soils microflora. In: Interactions between herbicides and the soil. ( Hance R.J ed.)pp 223-253.Academic press, London,UK.

Hernot J. and Robertson G. P. (1994). Vegetation removal in two soils of the humid tropics: Effect of microbial biomass. Soil Biol. and Biochem., 26: 111-116.

Huda M. M. (2009). Effect of Organic, Inorganic and Biofertilizers on Growth, Yield and
Physiological Activities of Soybean Crop. M.Sc. Thesis, Botany Department, Fac. of Sci. Sohag Univ.,Egypt.

Hui-lian X., Feifei Q., Wang F., Qicong X., Shailendra K. and Fengmin L. (2009). Integrated dryland weed control in nature farming systems. J. Food, Agric. \& Environ. 7(3\&4):744- 749.

Jackson M. L. (1967). Soil Chemical Analysis. Prentice-Hall, Inc., Englewood Cliffs, New Jersey, USA.

Jackson M. L. (1958). Soil Chemical Analysis. Constable \& Co. Ltd. London,UK.

Janssens I.A., Dieleman W., Luyssaert S., Subke J-A., Reichstein M., Ceulemans R., Ciais P., Dolman A. J., Grace J., Matteucci G., Papale D., Piao S. L., Schulze E-D., Tang J. and Law B.E. (2010). Reduction of forest soil respiration in response to nitrogen deposition. Nature Geosci., 3: 315- 322.

Kelly S., Ramirez A., Joseph M., Craine B. and Fierer N. (2010). Nitrogen fertilization inhibits soil microbial respiration regardless of the form of nitrogen applied. Soil Biol. \& Biochem., 42: 2336-2338.

Khuntia A. Pradhan M.R., Jena S. and Lenka P.C. (2013). Effect of Herbicides Soil Microbial Population and Productivity of Rice in North Eastern Coastal Plain Zone of Odisha. ISSN (Print)2347-7601, ISSN (Online) 2347-261X, Volume-1, Issue-1, 2013.

Kravchenko I., Kizilova A., Titova L. and Iutinskaya G. (2013). Effect of Microbial Fertilizers on Rhizospheric Bacterial Diversity and Yield Response of Soybean Plants. Agric. Sci. Develop., 2 (12): 120-125.

Lv W.G., Huang Q.W. and Shen Q.R. (2005). The effect of organic fertilizer and organicinorganic fertilizer application on soil enzymes activities during watermelon growing period. J. of Nanjing Agri. Univ., 28: 67-71.

Martin J. P. (1950). Use of acid, rose bengal and streptomycin in the plate method for estimating soil fungi. Soil Sci., 69: 215-32.

Mclaron A. D. and Peterson G. H. (1967). Introduction to the Biochemistry of Terrestrail Soils. In Soil Biochemistry. A.D. Mclaron and G. H. Peterson, Eds., pp.1- 15. Edward Arnold Ltd.(Publishers),London,UK.

Milosevic N.A. and Govedarica M.M. (2002). Effect of herbicides on microbiological properties of soil. Proc. Nat. Sci., 102: 5-21. 
Mohamed G. M. and Ezzat N. G. (1996). Phosphorus fertilization and inoculation in relation to soybean yield and seed quality. Fayoum J. Agric. Res., 10 (1): 48- 63.

Monkiedje A., Ilori M.D. and Spitelle, M. (2002). Soil quality changes resulting from the application of the fungicides mefenoxam and metalaxyl to a sandy loam soil. Soil Biol. Biochem., 34: 1939-1948.

Salas M.L., Hickman M.V., Huber D.M. and Schreiber M.M. (1997). Influence of nitrate and ammonium nutrition on the growth of giant foxtail (Setaria faberi). Weed Sci., 45: 664-669.

Sarathchandra S.U., Ghani A., Yeates G.W., Burch G. and Cox N.R. (2001). Effect of nitrogen and phosphate fertilizers on microbial and nematode diversity in pasture soils. Soil Biol. Biochem., 33: 953-964.

Schloter M., Dilly O. and Munch J.C. (2003). Indicators for evaluating soil quality. Agric. Ecosyst. Environ., 98: 255-262.
Sha H. Z. (2004). Test on the efficacy of $40 \%$ emulsifiable concentrate of Prometryn and acetochlor against soybean weeds. J. Jilin Agric. Univ., 26 (4): 452-454.

Soliman S., Galal Y. G. and El-Ghandour I. A. (1995). Soybean biofertilization in sandy soils of Egypt using $15 \mathrm{~N}$ tracer technique. Folia Microbiol., 40 (3): 321-326.

Torstensson L. (1980). Role of microorganisms in decomposition. In:Hance R.J.(Ed),Swedish EPA Uppsala, Report 4262,1993: 34.

Zayed A. (2003). Growth promotion of some soybean cultivars by Rhizobium and phosphate-solublilizing bacteria. Mansoura. J. Agric. Sci., 28 (10): 7481-7490.

Zhang J., Qin J., Yao W., Bi1 L., Lai T. and Yu X. (2009). Effect of long-term application of manure and mineral fertilizers on nitrogen mineralization and microbial biomass in paddy soil during rice growth stages. Plant soil environ., 55 (3): 101-109.

$$
\begin{aligned}
& \text { تأثير التسميد وبعض مبيدات الحثائش علي الحشائش و الكائنات الحية الدقيقة وإنتاجية فول الصويا } \\
& \text { عادل احمد عمران فكار ـ عبده عبيد أحمد إسماعيل ـمصطقي حمدان احمد محرم* } \\
& \text { المعمل المركزي لبحوث الحشائش ـ مركز البحوث الزر اعيةـ الجيزةـ مصر }
\end{aligned}
$$

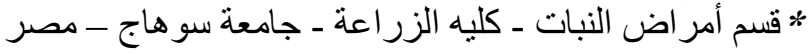

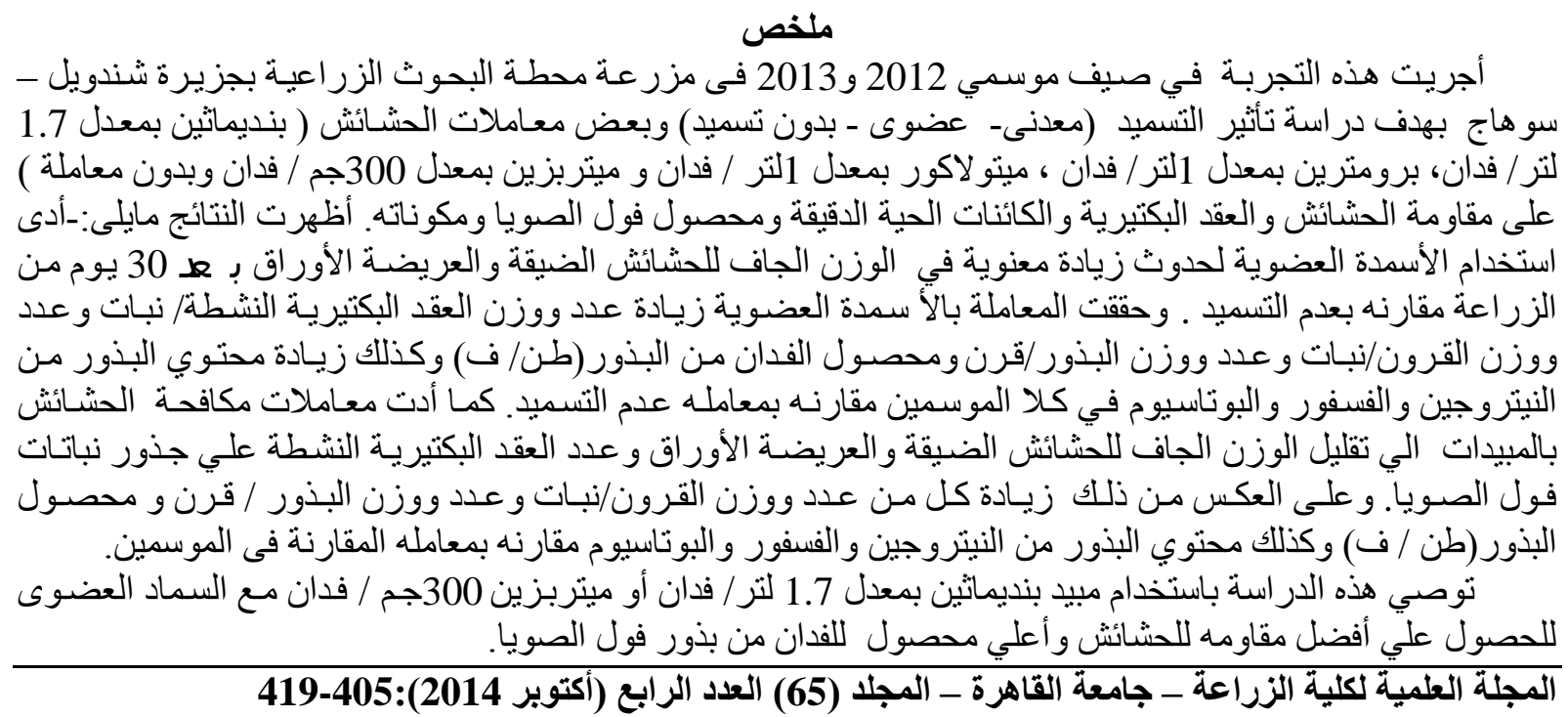

